\title{
Eco-Theology dalam Kisah Penciptaan
}

\author{
Hasiholan Sihaloho, Martina Novalina \\ Sekolah Tinggi Teologi Ekumene, Jakarta \\ hasiholan.sihaloho@sttekumene.ac.id,martina@sttekumene.ac.id
}

\begin{abstract}
The world is currently faced with a serious problem that determines the survival of humankind and the universe, namely the environmental crisis. The crisis can be caused by two factors: environmental factors or human factors. Various perspectives are used to be able to find the root of the problem, including religion in it. In Christianity, issues related to this are discussed in eco-theology. This article intends to examine eco-theology based on the creation story. The method used is qualitative research, where the description of the phenomena found is used as a background to the problem, which will then be discussed in depth through biblical literature studies from books, journals, and other sources related to the topic of discussion. The result is that chaos is a reality rejected by Allah. The presence of Christians must bring order to the natural surroundings. This will show the authenticity of the Christian faith. Obedience to the mandate of creation is a form of human responsibility at the end of time. Those who are obedient will enjoy God's Kingdom, both now and in the future.
\end{abstract}

Keywords: covenant; creation; eco-theology; eschatology; kingdom of God

\begin{abstract}
Abstrak
Dunia saat ini sedang diperhadapkan pada satu persoalan serius yang menentukan keberlangsungan hidup umat manusia dan alam semesta, yakni krisis lingkungan. Krisis tersebut dapat disebabkan oleh dua faktor: faktor lingkungan atau faktor manusia. Berbagai perspektif digunakan untuk bisa mencari akar permasalahannya, termasuk agama di dalamnya. Dalam kekristenan, permasalahan yang berkaitan dengan hal ini dibahas dalam eco-theology. Artikel ini hendak meneliti tentang eco-theology berdasarkan kisah penciptaan. Metode yang digunakan adalah penelitian kualitatif, di mana pemaparan akan fenomena yang ditemukan dijadikan sebagai latar belakang masalah, yang kemudian akan dibahas secara mendalam melalui kajian literatur secara biblikal dari buku-buku, jurnal, maupun sumber-sumber lain yang berkaitan dengan topik bahasan. Hasil yang didapat adalah bahwa kekacau balauan adalah realitas yang ditolak oleh Allah. Kehadiran orang Kristen harus menimbulkan keteraturan pada alam sekitarnya. Hal inilah yang akan menunjukkan kesejatian iman Kristen. Ketaatan akan mandat penciptaan merupakan wujud pertanggungan jawab manusia di akhir zaman nanti. Mereka yang taat akan menikmati Kerajaan Allah, baik sekarang maupun yang akan datang.
\end{abstract}

Kata kunci: eco-theology; eskatologis; Kerajaan Allah; penciptaan; perjanjian

\section{PENDAHULUAN}

Beberapa waktu yang lalu (tahun 2015) Indonesia dilanda masalah lingkungan yang cukup parah dimana terjadi kebakaran hutan di berbagai daerah yang berujung kepada masalah kabut asap yang mengganggu ekosistem maupun aktivitas manusia sehari-hari dalam waktu yang cukup lama. Rakyat semakin resah dan pemerintah semakin tertekan untuk menemukan jalan keluar dari masalah asap. Rakyat di Pekanbaru, Riau, Sumatra dan Palangkaraya, Kalimantan Tengah menderita kabut asap selama berbulan-bulan. 
Ratusan ribu warga mengalami dampak kesehatan. Hal ini pun berulang kembali pada tahun 2019. ${ }^{1}$

Adanya kebakaran hutan tersebut tentu saja dapat disebabkan oleh dua hal, yaitu faktor alam atau faktor manusia. Dari faktor alam dapat diprediksikan bahwa iklim $\mathrm{El}$ Nino menjadi salah satu penyebab terjadinya kerusakan lingkungan ini, di mana musim kemarau terjadi lebih lama dari biasanya ${ }^{2}$, walaupun memang El-Nino tidak secara langsung menjadi penyebabnya. Kondisi udara kering, ditambah sedikitnya curah hujan telah membuat api menjadi mudah berkobar dan merambat, serta sulit dikendalikan. Dari faktor manusia, disebabkan oleh karena adanya kelalaian dalam menjaga lingkungan hidup, sebagai contohnya: manusia merusak hutan dengan cara membakar hutan tanpa mengikuti prosedur yang benar. Kerusakan hutan tersebut membawa banyak konsekuensi. Lembaga Ilmu Pengetahuan Indonesia menginformasikan bahwa Indonesia memecahkan rekor Guinnes World Record sebagai negara penghancur hutan tercepat. ${ }^{3}$

Melihat fakta yang ada, maka tidak salah jika manusia pun dikatakan memiliki andil dalam rusaknya alam dan bumi yang sedang 'sekarat' ini. Belum lagi jika melihat contoh masalah lingkungan lainnya seperti banjir bandang Sentani yang juga diakibatkan oleh ulah manusia yang menjadikan daerah resapan air sebagai area pemukiman ${ }^{4}$, dan pencemaran udara akibat aktivitas manusia seperti pembakaran bahan bakar fosil, kegiatan pertanian, kegiatan industri, kegiatan penambangan, kegiatan militer manusia, dan produk rumah tangga. ${ }^{5}$

Agama merupakan dimensi kehidupan yang selama ini cenderung terlupakan dalam permasalahan lingkungan hidup. Tentunya, hal ini menjadi lumrah dan dimaklumi ketika melihat bahwa pemahaman masyarakat terhadap agama umumnya masih berkutat pada masalah ritualistik saja. Padahal, pada dasarnya agama mengatur prinsip hidup di dunia. Namun, dengan fungsi eskatologisnya, motivasi agama tidaklah sama dengan motivasi dalam prinsip-prinsip civic yang mengacu pada hidup bersama di dunia secara inklusif-pengakuan akan kesetaraan setiap warga negara, tanpa keberpihakan pada agama, ras dan etnisitas. ${ }^{6}$

Bagi beberapa kalangan menyebut istilah agama selalu diartikan sebagai penunjuk terhadap seperangkat ritual agama, baik itu ibadah maupun perayaan hari-hari suci, pada hal ruang lingkup jangkauan agama lebih dari itu. Masalah ini pun tidak luput di dalam kekristenan. Sangat jarang ajaran di dalam gereja berbicara tentang studi penciptaan yang berkaitan dengan alam. Gereja lebih sering membahas tentang pokok-pokok dok-

\footnotetext{
1“Kebakaran Hutan Dan Lahan Kian Meluas Dan Kabut Asap Semakin Parah, BNPB Kewalahan Padamkan Api," BBC News Indonesia, last modified 2019, https://www.bbc.com/indonesia/indonesia49708970.

${ }^{2}$ cnnindonesia, "No Title," last modified 2015, M.cnnindonesia.com.

${ }^{3}$ Civitas LIPI, "No Title," last modified 2015, lipi.go.id.

${ }^{4}$ VOA Indonesia, "BNPB: Banjir Bandang Sentani Akibat Ulah Manusia Yang Merusak Alam," VOA Indonesia, last modified 2019, accessed December 21, 2020,

https://www.voaindonesia.com/a/bnpb-banjir-bandang-sentani-akibat-ulah-manusia-yang-merusakalam/4836093.html.

${ }^{5}$ Kompas.com, "Penyebab Pencemaran Udara - Kompas,” 2020, accessed December 21, 2020, https://www.kompas.com/skola/read/2020/01/17/100000469/penyebab-pencemaran-udara?page=all.

${ }^{6}$ Martina Novalina, "Spiritualitas Orang Kristen Dalam Menghadirkan Kerajaan Allah Di Tengah Tantangan Radikalisme," Jurnal Teologi Kontekstual Indonesia 1, no. 1 (June 29, 2020): 26, https://journal.sttsimpson.ac.id/index.php/JTKI/article/view/293.
} 
trinal seperti soteriologi, kristologi, eklesiologi, dogmatik dan lain-lain padahal studi tentang penciptaan memegang peranan penting pula di dalam pertumbuhan iman Kristiani dalam kehidupan manusia dan adanya Kerajaan Allah dalam kehidupan manusia. Tujuan akhir Allah adalah agar kerajaan-Nya didirikan di atas segala ciptaan. ${ }^{7}$

Rolf Rendtorff menyatakan bahwa kisah penciptaan memberi konteks untuk tindakan penebusan sehingga karya Tuhan dalam penciptaan sama pentingnya dengan karya keselamatan-Nya dalam sejarah. ${ }^{8}$ Begitu pula dengan Brevard Childs yang mengusulkan untuk melihat karya penciptaan dan keselamatan sebagai suatu interaksi yang korelatif. ${ }^{9}$ Pernyataan ini diperjelas lagi dengan pendapat Claus Westermann yang menyatakan bahwa bila teologi dan khotbah gereja hanya berurusan dengan keselamatan; bila Allah berurusan dengan manusia sebatas pengampunan dosa atau pembenaran, maka konsekuensi yang tak dapat dielakkan adalah bahwa hanya dalam konteks inilah manusia berurusan dengan Allah dan Allah berurusan dengan manusia. Hal ini berarti bahwa Allah tidak peduli dengan cacing yang terinjak atau dengan penampakan bintang baru dalam gugusan Bima Sakti. Ia mempertanyakan apakah akhirnya sains telah menjadi tuan dari wilayah yang dulu disebut ciptaan? Apakah Allah peduli dengan dunia real di sekitar manusia? Penciptakah Dia? ${ }^{10}$ Pertanyaan retorik Westermann tentunya tidak bisa dianggap sebagai sebuah angin lalu dalam dunia teologi. Kegundahan teologis akan masalah lingkungan perlu mendapat perhatian yang mendalam melalui kajian yang memadai. Oleh karena itu, artikel ini berisi sebuah pembahasan tentang eco-theology dalam kisah penciptaan.

\section{METODE}

Metode yang digunakan adalah penelitian kualitatif, dimana pemaparan akan fenomena yang ditemukan dijadikan sebagai latar belakang masalah, yang kemudian akan dibahas secara mendalam melalui kajian literatur dari buku-buku, jurnal, maupun sumbersumber lain yang berkaitan dengan topik bahasan. Metode literature review ini dilakukan mengingat permasalahan yang akan dikaji hanya bisa dijawab melalui penelitian pustaka, dimana kajian mengenai kisah penciptaan ada dalam Alkitab maupun bukubuku, serta jurnal pendukung lainnya. Peneliti juga melihat bahwa data pustaka dianggap tetap andal untuk memberikan jawaban terhadap persoalan penelitian yang memuat informasi data empiris yang diteliti oleh orang lain namun tetap dapat digunakan sebagai sumber-sumber literature review. Metode ini pun menjadi tahap yang berguna untuk peneliti melakukan studi pendahuluan dimana dalam tahap ini dapat ditemukan dan dipahami lebih jauh gejala-gejala baru mengenai eco-theology yang tengah berkembang di dalam masyarakat. ${ }^{11}$

${ }^{7}$ David L. Baker, Satu Alkitab Dua Perjanjian, 9th ed. (Jakarta: BPK Gunung Mulia, 2015).

${ }^{8}$ Rolf Rendtorff, "'Where Were You When I Laid the Foundation of the Earth?: Creation and Salvation History,"” in Bunga Rampai Teologi Perjanjian Lama, 7th ed. (Jakarta: BPK Gunung Mulia, 2015), 25.

${ }^{9}$ Brevard Childs, "Old Testament Theology in a Canonical Context," in Bunga Rampai Teologi Perjanjian Lama, 7th ed. (Jakarta: BPK Gunung Mulia, 2015).

${ }^{10}$ Claus Westermann, “Creation,” in Bunga Rampai Teologi Perjanjian Lama, 7th ed. (Jakarta: BPK Gunung Mulia, 2015), 20-21.

${ }^{11}$ Agustin Soewitomo Putri, “Tips Dan Trik Pemilihan Dan Penyusunan Literatur Review," in Strategi Menulis Jurnal Untuk Ilmu Teologi (Golden Gate Publishing, 2020), 49-50. 


\section{HASIL DAN PEMBAHASAN}

\section{Eco-theology}

Pembahasan tentang eco-theology bukanlah sebuah hal yang langka dalam dunia akademis. Sudah ada beberapa kajian ilmiah yang berkaitan dengan topik ini, seperti ecotheology ditinjau dari wawasan gender dalam Al-Quran yang mengatakan bahwa interkoneksi antara manusia dengan manusia, lingkungan dan Tuhan yang harmonis tidak terlepas dari peran laki-laki dan perempuan yang komplementer dan kooperatif dalam relasi gender termasuk dalam upaya konservasi lingkungan ${ }^{12}$, Apa Hubungan Porong dengan Yerusalem: Menggagas Suatu Ekoteologi Kristen yang mengatakan bahwa terdapat korelasi timbal balik antara iman Kristen dan krisis lingkungan hidup yang disebabkan oleh manusia ${ }^{13}$, Beyond Ecotheology yang berpendapat bahwa tidak ada proyek teologis yang bertanggung jawab yang mampu mengabaikan keprihatinan yang telah diperjuangkan oleh ekoteologi hingga saat ini. ${ }^{14}$ Namun demikian, bukan berarti apa yang akan diteliti dalam artikel ini merupakan hal yang sama dengan pembahasan-pembahasan di atas. Penelitian ini mengambil dimensi yang berbeda dari eco-theology, yaitu kaitannya dengan kisah penciptaan yang dikaji dengan kajian biblika.

Dasar pemahaman teologi lingkungan (Eco-Theology) adalah kesadaran bahwa krisis lingkungan tidak semata-mata masalah yang bersifat sekuler, tetapi juga problem keagamaan yang akut karena berawal dari pemahaman agama yang keliru tentang kehidupan. Melalui teologi lingkungan, dilakukan kaji ulang terhadap pemahaman-pemahaman agama di tengah masyarakat, utamanya mengenai posisi manusia dan tanggung jawabnya berkaitan dengan alam yang didiaminya selama ini. Manusia dan alam merupakan dua entitas yang tidak dapat dipisahkan. Tidak ada posisi ordinat dan subordinat antar keduanya.

Eco-Theology berusaha mengungkap dasar teologis untuk hubungan yang tepat antara Tuhan, kemanusiaan dan kosmos. Banyak pendekatan terhadap Eco-Theology adalah pendekatan yang berusaha memulihkan pengertian akan tempat di bumi, mengingatkan bahwa bumi adalah rumah bersama, bahwa kisah tentang bumi dan tentang manusia adalah satu. ${ }^{15}$ Berbagai problem lingkungan ini riil, dan termasuk konsekuensikonsekuensi modernitas yang paling serius. Sering dituduhkan bahwa karena dunia modern dibentuk oleh pengaplikasian ide-ide yang ditumbuhkan oleh kekristenan secara ilmiah dan teknologis maka ancaman-ancaman lingkungan dari modernitas ini disebabkan oleh cacat-cacat yang serius dari ide-ide Kristen.

Wilkinson melihat ada beberapa tuduhan lingkungan yang dilontarkan terhadap kekristenan antara lain ialah (1) Penciptaan oleh Allah yang patriakhal dan transenden (yang berarti terpisah dari ciptaan-Nya); (2) Penciptaan manusia di dalam gambar Allah (dengan demikian memberikan kepada manusia status di atas ciptaan lainnya secara tan-

${ }^{12}$ Nur Arfiyah Febriani, “Ekoteologi Berwawasan Gender Dalam Al-Quran,” PALASTREN Jurnal Studi Gender 10, no. 1 (April 5, 2017): 67,

http://journal.stainkudus.ac.id/index.php/Palastren/article/view/2463.

${ }^{13}$ Ferry Yefta Mamahit, “Apa Hubungan Porong Dengan Yerusalem? : Menggagas Suatu Ekoteologi Kristen” (2007), http://repository.seabs.ac.id/handle/123456789/144.

${ }^{14}$ David Clough, "Beyond Ecotheology," Theology 116, no. 1 (January 10, 2013): 47-49, http://journals.sagepub.com/doi/10.1177/0040571X12461231.

${ }^{15}$ Celia Deane-Drummond, "Eco-Theology” (January 1, 2008). 
pa batas); (3) Pemberian 'kekuasaan' kepada manusia, yang berarti mengizinkan mereka untuk melakukan apa saja yang mereka inginkan terhadap ciptaan; (4) Doktrin 'jatuhnya alam,' yang melihat proses-proses alam (termasuk kematian) sebagai hal yang pada dasarnya jahat; (5) Doktrin keselamatan yang hanya menjanjikan 'hidup kekal' kepada umat manusia, sehingga menjadikan semua ciptaan lain sebagai latar atau sarana bagi keselamatan manusia; (6) Pandangan akan sejarah yang mendorong ide tentang kemajuan yang bersifat merusak itu; (7) Skala waktu pendek yang menghambat apresiasi terhadap evolusi dan dengan demikian juga terhadap ekologi; (8) Mendorong sains dan teknologi melalui desakralisasi ciptaan, melalui keyakinan akan kecerdasannya, dan melalui penegasan akan kelayakan kuasa manusia atasnya. ${ }^{16}$

Beberapa tuduhan yang dipaparkan Wilkinson didukung oleh Lynn White, yang menyatakan bahwa kekristenan sebagai agama paling antroposentris di dunia dan menanggung beban kesalahan yang berat atas berbagai problem lingkungan. ${ }^{17}$ Salah satu poin yang dikritik oleh White adalah teks Kejadian 1:28 yang berbicara tentang mandat yang diterima manusia untuk berkuasa atas bumi dan segala isinya. Itulah mengapa, orang Kristen harus mengerti dengan jelas isi dan bentuk sastra dari kitab Kejadian untuk dapat bertahan menghadapi tantangan tersebut. ${ }^{18}$

Membangun eco-theology dari teks-teks alkitabiah sangatlah rumit dan sama sekali bukan proses yang langsung. Untuk mengatakan sesuatu yang bermakna tentang eco-theology dan Alkitab memerlukan pemikiran ulang total dari hermeneutika alkitabiah. Alasannya adalah karena Alkitab Yahudi-Kristen mengatakan sangat sedikit tentang alam dan lingkungan, dan dalam kasus-kasus yang menyinggung dunia alami, sebagian besar Alkitab seolah-olah acuh tak acuh. ${ }^{19}$

Masalah tentang teologi lingkungan ini tidak terlepas dari karya penciptaan yang ada dalam Alkitab. Alkitab secara eksplisit menggambarkan hubungan antara mandat penciptaan dengan perjanjian. Ketika Allah menciptakan manusia, Allah memberi amanat penciptaan sebagai perjanjian. Perjanjian Allah dengan Adam terungkap dalam bentuk sanksi perjanjian. Kedaulatan yang diberikan Allah akan bertahan jika manusia dapat melalui pencobaan. Takdir eskatologis adalah suatu bentuk pilihan: abadi atau celaka. Hidup untuk selama-lamanya sebagai sanksi berkat, dan muncul dalam sejarah penebusan oleh Yesus Kristus: "...setiap orang yang hidup dan yang percaya kepada-Ku, tidak akan mati selama-lamanya..." (Yoh. 11:26); "Dalam Dia ada hidup dan hidup itu adalah terang manusia" (Yoh. 1:4); dan, Paulus dalam Roma 5:19 menyatakan bahwa "Jadi sama seperti oleh ketidaktaatan satu orang semua orang telah menjadi orang berdosa, demikian pula oleh ketaatan satu orang semua orang menjadi orang benar".

${ }^{16}$ Loren Wilkinson, "Kegundahan Hati Nurani Umat Manusia: Menemukan Kembali Ciptaan Di Dalam Gerakan 'Lingkungan' Dalam Allah Dan Kebudayaan,” in Kumpulan Esai Untuk Memperingati Ulang Tahun Carl F. H. Henry Ke-80, ed. John D. Carson, D. A. \& Woodbridge (Surabaya, 2011).

${ }^{17}$ Ibid.

${ }^{18}$ Charles Waltke, Bruce K.; Yu, An Old Testament Theology (Grand Rapids: Zondervan, 2007).

${ }^{19}$ Peet Van Dyk, "Eco-Theology: In and out of the Wilderness," Old Testament Essays 30 (December 1, 2017). 
Meredith G. Kline menyatakan bahwa teologi perjanjian umumnya mengambil posisi bahwa konsep perjanjian dapat menampung seluruh sejarah kerajaan Allah. ${ }^{20}$

\section{Penciptaan}

Narasi awal dari penciptaan bukan hanya membuka drama alam semesta dari tema Alkitab, namun merupakan sebuah dasar dari cara pandang Alkitabiah yang monoteisme. Allah menjadikan surga sebagai tahta-Nya dan bumi sebagai tempat pijakannya; menunjuk manusia sebagai pengawas untuk memerintah di bumi dan menetapkan hukum bagi Israel dalam rangka penciptaan. Antropolog budaya pada umumnya menganggap budaya alam semesta akan menyerap persepsi dan pemikiran rakyat. Kisah penciptaan mewakili Allah sebagai penyelamat yang berdaulat yang mengubah kegelapan menjadi ciptaan yang baik yang menghasilkan dan menopang kehidupan. ${ }^{21}$

Kekuasaan Allah atas dunia tidak hanya berlaku pada waktu penciptaan pada awalnya, tetapi terus berlangsung dalam tegaknya dunia. Hubungan kebergantungan ini tidak bersifat narsistik sebab dunia dijadikan bukan demi kesenangan Tuhan, melainkan agar di dalam dunia tumbuh keselamatan dan keadilan (Yes. 45:8). ${ }^{22}$ Allah sebagai Pencipta segalanya dan Penguasa atas alam semesta merupakan pernyataan yang paling penting dalam narasi penciptaan. Sebagai Pencipta alam semesta, Ia menang dimasa lalu, sebagai Pencipta sejarah, Ia menang dimasa kini, dan sebagai Pencipta atas langit dan bumi baru, ketika penciptaan mencapai puncaknya, Ia akan menang di masa depan (Yes. 65:17; 66:12; 2 Petrus 3:13; Wah. 21:1). ${ }^{23}$

Struktur dan teks narasi (Kej. 1:1-2:3) tentang penciptaan dapat dijabarkan sebagai berikut ${ }^{24}$ :

Kejadian 1:1, Pernyataan ringkasan. Kej. 1:1 merupakan kata pengantar dari seluruh narasi. Kalau ayat 1 merupakan ringkasan, maka kalimat "pada mulanya" harus mengacu kepada enam hari pertama penciptaan, bukan waktu sebelum penciptaan. Enam hari merupakan apa yang dimaksud dengan "pada mulanya".

Kejadian 1:2, Keadaan negatif bumi sebelum penciptaan. Pernyataan ringkasan menyatakan bahwa kekacau balauan (bumi belum berbentuk dan kosong) dalam ayat 2 tidak hadir sendiri dari Allah, tetapi teks tidak menjelaskan hubungan antara Allah dengan kekacau balauan. Sebaliknya, ayat 2 menyediakan konteks untuk menafsirkan pentingnya penciptaan - yaitu, perjanjian Israel - Tuhan mengatasi kekacauan untuk mewujudkan kehendak-Nya. Kekacau balauan adalah realitas yang ditolak oleh Allah.

Ketika penulis Ibrani mengatakan bahwa alam semesta telah dijadikan oleh Allah (Ibrani 11:3), ia tidak memasukkan kegelapan di dalamnya karena kegelapan terpisah dan ada sebelum perintah Allah. Yohanes 1:3 mengatakan bahwa segala sesuatu dijadi-

${ }^{20}$ Meredith G. Kline, Kingdom Prologue, Genesis Foundations for a Covenantal Worldview (Overland Park: Two Age Press, 2000).

${ }^{21}$ Yongky Karman, Bunga Rampai Teologi Perjanjian Lama, 7th ed. (Jakarta: BPK Gunung Mulia, 2015).

${ }^{22}$ Roy Charly Sipahutar, "Kajian Ekoteologis Tentang Konsep Tanah Dalam Perjanjian Lama Dan Implikasinya Bagi Pemeliharaan Tanah,” BIA': Jurnal Teologi dan Pendidikan Kristen Kontekstual 2, No. 2 (2019).

${ }^{23}$ Waltke, Bruce K.; Yu, An Old Testament Theology.

${ }^{24}$ Ibid. 
kan oleh Dia dan tanpa Dia tidak ada suatu pun yang telah jadi dari segala yang telah dijadikan, namun apakah kegelapan itu pernah terkonsep dalam Alkitab?

Penulis kitab Ayub menuliskan "Siapa telah membendung laut dengan pintu, ketika membual ke luar dari dalam rahim? ketika Aku membuat awan menjadi pakaiannya dan kekelaman menjadi kain bedungnya" (Ay. 38:8-9), tetapi tidak jelas bahwa teks Alkitab menyatakan asal keberadaan dari kekacau balauan maupun Iblis. Jawaban figuratif terdapat dalam Yehezkiel 28 dan Wahyu 13; tetapi jawaban ini tidak dapat menjadi dasar yang kuat untuk dijadikan sebuah dogma.

Karena kegelapan akan tersingkir di langit dan bumi yang baru (Why. 21-22), maka kegelapan tidaklah kekal; awal kegelapan adalah misteri. Tidak adanya data bukan argumen untuk sebuah dualisme abadi. "Belum berbentuk dan kosong" ini menunjukkan indikasi negatif, keadaan bumi yang "tidak baik".

\section{Penciptaan oleh Firman Allah (Kej. 1:3-31).}

1. Proses penciptaan.

- Pemberitahuan, "berfirmanlah Allah" (Kej. 1:3, 6, 9, 11; 14, 20, 24, 26). Dengan menetapkan Firman sebelum melakukan, menunjukkan bahwa alam semesta diciptakan oleh Satu Pribadi, Tuhan; Tuhan yang berpikir dan mengatur semuanya menurut kehendak-Nya. Hal ini mematahkan opini bahwa Tuhan hanyalah sebuah kekuatan tanpa perenungan rasio dan menghilangkan prasangka mitos bahwa bagian-bagian yang berbeda dari dunia adalah pancaran yang keluar dari dewa.

- Perintah, "Jadilah...", menyatakan bahwa alam semesta tercipta oleh kehendak Allah dan Firman-Nya, yang mengatasi keadaan negatif dari bumi. Kekuatan kata-kata tergantung kepada siapa yang berbicara bukan pada kata-kata itu sendiri. Sebagai contoh: kuasa dari sebuah institusi dapat mengumumkan seorang pria dan wanita menjadi suami dan istri, maka jadilah. Seorang hamba Tuhan dapat membaptis orang dalam nama Bapa, Anak dan Roh Kudus, maka jadilah. Begitu pula dengan Allah yang Mahakuasa yang memfirmankan penciptaan menjadi sebuah keberadaan, maka jadilah.

- Laporan, "Maka Allah menjadikan..." menunjukkan kedaulatan-Nya atas segala sesuatu, termasuk laut; air yang berkumpul dan daratan yang kering.

- $\quad$ Allah memberi nama elemen dalam alam semesta, menyebut terang sebagai siang dan kegelapan sebagai malam. Air yang berkumpul sebagai laut, tanah kering sebagai daratan. Kekuatan untuk memberi nama menunjukkan kekuasaan. Di timur dekat kuno, ketika seorang raja menguasai orang lain, ia mengubah nama mereka untuk menunjukkan kekuasaannya (Bil. 32:38).

- Tuhan mengevaluasi penciptaan dengan standar-Nya dan menyatakannya "baik". Semua yang Ia ciptakan berfungsi sebagaimana yang Ia maksudkan.

- Strukturnya diakhiri dengan kerangka kronologis: "Jadilah petang dan jadilah pagi, itulah hari pertama." Kerangka kronologis menunjukkan logika dari penciptaan Tuhan, itupun menunjukkan kemajuan, dengan ruang angkasa yang ditandai dengan bola matahari. Tanpa ruang angkasa dan benda-benda langit, maka tidak ada waktu. Tuhan tidak menciptakan dalam waktu, Ia menciptakan dengan waktu sebagai cara mudah untuk mengukur perkembangan sehubungan dengan ruang angkasa. 
Perkembangan penciptaan.

Kisah penciptaan dibagi menjadi 2 bagian seperti di bawah ini:

\begin{tabular}{|c|c|c|c|}
\hline Hari ke- & Bentuk $(t \bar{o} h \hat{u})$ & Hari ke- & Isi $(b \bar{o} h \hat{u})$ \\
\hline 1 & Terang (ayat 3-5) & 4 & Benda-benda penerang (ay. 14-19) \\
\hline 2 & $\begin{array}{cc}\text { Cakrawala (ay. 6-8) } \\
-\quad \text { Langit } \\
-\quad \text { Laut } \\
\end{array}$ & 5 & $\begin{aligned} \text { Penghuni (ay. 20-23) } \\
-\quad \text { Ikan } \\
-\quad \text { Burung-burung }\end{aligned}$ \\
\hline 3 & $\begin{array}{l}\text { Lahan kering/darat (ay. 9-10) } \\
\text { Tumbuh-tumbuhan (ay. 11-12) }\end{array}$ & 6 & $\begin{array}{l}\text { Hewan darat (ay. 24-26) } \\
\text { Manusia (ay. 27-31) }\end{array}$ \\
\hline
\end{tabular}

Beberapa pengamatan pada pola ini menghasilkan pernyataan yang penting: catatan: tiga serangkai pertama yang dimaksud adalah hari ke 1-3 sedangkan tiga serangkai yang kedua adalah hari ke 4-6.

Pertama, tiga serangkai pertama melibatkan pemisahan dari yang tak berbentuk menjadi tiga bidang statis. Tiga serangkai yang kedua memenuhi tiga bidang tersebut.

Kedua, elemen dari tiap tiga serangkai berkembang dari surga ke bumi. Tiga serangkai pertama dimulai dengan penciptaan langit dan berakhir dengan penciptaan tumbuh-tumbuhan. Tiga serangkai kedua dimulai dengan penciptaan benda-benda langit dan berakhir dengan penciptaan Adam dalam gambar Allah.

Ketiga, kedua bagian dari tiga serangkai memiliki struktur yang sama.

Keempat, penghuni (hari ke -5) dalam tiga serangkai kedua menguasai bidang yang diberikan.

Kelima, kedua bagian dari tiga serangkai itu dibedakan oleh gerakan. Tiga serangkai pertama bersifat statis - tidak bergerak, tiga serangkai kedua dipenuhi oleh gerakan.

Keenam, dari pemaparan proses penciptaan dan perkembangan penciptaan di atas, dapat dilihat bahwa narasi penciptaan adalah kisah penebusan, terang atas kegelapan, tanah dan langit di atas air, yang keduanya penting bagi kehidupan, dan bagaimana Allah menciptakan manusia menjadi rekan sekerjanya dalam mengelola ciptaanNya. Pengelolaan ciptaan Allah tentunya harus dilakukan dengan benar, dan inilah yang tercakup dalam sebuah konsep ekoteologi yang diawali dari sebuah narasi penciptaan.

Ketujuh, mengelola ciptaan di bumi ini tentunya bukan berarti membuat manusia menjadi lupa akan rumah abadinya, yaitu Sorga. Pengharapan eskatologis masih tetap menjadi sebuah keharusan yang dimiliki oleh pengikut Kristus sebagaimana yang dijanjikan-Nya dalam Yohanes 14:2 "Di rumah Bapa-Ku banyak tempat tinggal. Jika tidak demikian, tentu Aku mengatakannya kepadamu. Sebab Aku pergi ke situ untuk menyediakan tempat bagimu."

\section{Eskatologis}

Eskatologi memberikan visi akan keseimbangan ekologis yang sempurna di dalam bumi yang telah dipulihkan atau di dalam langit dan bumi baru. Eskatologi mungkin saja mengeluhkan bahwa para ekolog memberikan gambaran yang terlalu muluk tentang harmoni yang bisa dicapai saat ini dan bahwa mereka berupaya untuk menerapkan pembatasan yang terlalu eskesif pada gaya hidup, baik terhadap individu maupun masyarakat. Eskatologi menyadari bahwa alam sendiri di dalam keadaannya yang sekarang bisa menyebabkan gangguan. Eskatologi juga menyesalkan kecenderungan sejumlah ekolog untuk memberhalakan alam dan bukannya menyembah Allah yang Empunya 
alam ini, atau bahkan menempatkan diri mereka di dalam peran sebagai allah. Eskatologi menyatakan kebenaran bahwa Allah yang menciptakan dunia ini memiliki rencana untuknya yang akan digenapkan-Nya secara pasti.

Ketegangan pemikiran-pemikiran antara eskatologi dan eco-theology tidak mungkin dihindari, namun perlu disadari bahwa sebenarnya eskatologis dan eco-theology dapat berinteraksi secara konstruktif. Eco-theology telah menyadarkan gereja akan tanggung jawab manusia dalam kepenatalayanan di dalam ciptaan Allah. Hubungan utama di sini adalah dengan ciptaan dan pemeliharaannya. Namun Perjanjian Baru memberitahu bahwa penatalayanan merupakan hal yang harus diperhatikan sampai Tuhan datang (Mat. 24:45-51) sebagaimana yang telah dijelaskan sebelumnya.

Kepenatalayanan ini pertama-tama memang merujuk pada penyebaran rahasia Allah (1Kor. 4:1-2) sehingga perihal-perihal yang lebih tidak penting seharusnya jangan membelokkan orang-orang Kristen dari kewajiban yang utama ini. Tetapi orang juga bisa melihat bahwa acuan yang sah kepada kepenatalayanan dunia juga tertanam di dalam umat manusia pada saat penciptaan (Kej. 1:26). Bagi kepenatalayanan ini, akhir zaman berarti merupakan waktu untuk memberikan pertanggungan jawab. Tuhan sendiri sudah pasti akan membenahi semuanya pada saat kedatangan-Nya, baik dengan memperbaiki ciptaan lama terlebih dahulu atau langsung menciptakan penciptaan baru. Ia akan memberikan kata-kata penghargaan kepada mereka yang bekerja bagi integritas ciptaan dan kata-kata teguran bagi mereka yang menyalahgunakan karya-Nya demi kepentingan diri sendiri atau tujuan-tujuan yang fasik.

Tuntutan eskatologis akan kesetiaan di dalam mengelola berbagai sumber daya ini menegaskan pergeseran budaya dari eksploitasi lingkungan kepada perlindungan lingkungan, meskipun prosesnya begitu lambat. Setiap orang Kristen terpanggil untuk mengejawantahkan imannya dalam perilaku sehari-hari. Sehingga, komunitas masyarakat dan lingkungan akan segera berkembang ke arah yang jauh lebih baik. Suatu komunitas masyarakat dan lingkungan yang baik, hidup dalam 'Shalom'.

Shalom adalah tema sentral dalam Perjanjian Lama. Ini mencakup ide 'keutuhan,' 'kesejahteraan,' dan 'harmonis.' Shalom adalah konsep holistis bagi Israel dalam Perjanjian Lama dan orang-orang di sekitar mereka. Tidak ada dikotomi antara 'sakral' dan 'profan' dalam shalom. Dalam kesejahteraan, shalom meliputi rohani maupun jasmani. Dalam keharmonisan diekspresikan baik sebagai keadaan maupun hubungan. Ketika hubungan antara Allah, manusia, dan alam semesta ditemukan dalam totalitas keharmonisan, shalom akan termanifestasi secara penuh. Pusat kondisi ini terletak pada pengenalan akan ketuhanan Allah atas hubungan ketiganya (Allah, manusia, alam semesta). ${ }^{25}$

\section{KESIMPULAN}

Dari pemaparan tentang eco-theology, penciptaan, dan eskatologi maka dapat dilihat bahwa pemberian kekuasaan kepada manusia untuk memerintah dan menaklukkan bumi serta ciptaan lainnya seharusnya menjadikan manusia semakin bertanggung jawab dan bijaksana dalam penatalayanan dan memelihara ciptaan. Menundukkan dan memerintah atas alam tidak berarti mengeksploitasi bumi melainkan suatu tindakan mempelajari hu-

${ }^{25}$ Gideon Imanto Tanbunan, Shalom: Paradigma Holistis Dalam Perjanjian Lama Dalam MIsi Holistis (Jakarta dan Bandung: Institute for Community and Development Studies, 2003). 
kum alam; menyelidiki dan mengeksplorasinya. Tindakan tersebut bukan suatu pekerjaan yang ringan, karena diperlukan keseriusan dan kekuatan manusia. Memelihara lingkungan adalah bagian dari misi Allah dalam mendatangkan shalom Kerajaan Allah. Itu sebabnya orang Kristen, secara sendiri-sendiri atau sebagai institusi, wajib menjaga dan memelihara lingkungan hidup.

Ditinjau dari segi doktrin atau pemahaman iman Kristen, maka kepedulian terhadap lingkungan hidup tidak lagi perlu dipertanyakan. Barangkali yang menjadi persoalan adalah praktik dalam kehidupan sehari-hari setiap orang; masih kurangnya kepedulian terhadap krisis lingkungan hidup, antara lain: keyakinan iman belum diimplementasikan dalam keseharian hidup, agama masih bersifat seremoni atau baru pada tahap pengakuan iman merupakan faktor penyebabnya. Dengan mengamati dan mengetahui bahwa betapa pentingnya mandat yang Allah berikan kepada manusia dalam penatalayanan dan memelihara ciptaan, kiranya menjadikan gereja melalui hamba-hamba Tuhan untuk menjadikan suatu pengajaran yang tidak diabaikan melalui khotbah. Hal tersebut untuk tetap mengingatkan dan menghimbau orang-orang Kristen supaya tetap menjaga keharmonisan ciptaan-ciptaan lain sebagai salah satu bentuk ketaatan kepada Allah sebagai Sang Pencipta dan menghadirkan Kerajaan Allah di muka bumi.

\section{REFERENSI}

Baker, David L. Satu Alkitab Dua Perjanjian. 9th ed. Jakarta: BPK Gunung Mulia, 2015.

Childs, Brevard. "Old Testament Theology in a Canonical Context." In Bunga Rampai

Teologi Perjanjian Lama. 7th ed. Jakarta: BPK Gunung Mulia, 2015.

Clough, David. "Beyond Ecotheology.” Theology 116, no. 1 (January 10, 2013): 47-49. http://journals.sagepub.com/doi/10.1177/0040571X12461231.

cnnindonesia. "No Title." Last modified 2015. M.cnnindonesia.com.

Deane-Drummond, Celia. "Eco-Theology" (January 1, 2008).

Van Dyk, Peet. "Eco-Theology: In and out of the Wilderness." Old Testament Essays 30 (December 1, 2017).

Febriani, Nur Arfiyah. "Ekoteologi Berwawasan Gender Dalam Al-Quran." PALASTREN Jurnal Studi Gender 10, no. 1 (April 5, 2017): 67. http://journal.stainkudus.ac.id/index.php/Palastren/article/view/2463.

Karman, Yongky. Bunga Rampai Teologi Perjanjian Lama. 7th ed. Jakarta: BPK Gunung Mulia, 2015.

Kline, Meredith G. Kingdom Prologue, Genesis Foundations for a Covenantal Worldview. Overland Park: Two Age Press, 2000.

Kompas.com. "Penyebab Pencemaran Udara - Kompas," 2020. Accessed December 21, 2020. https://www.kompas.com/skola/read/2020/01/17/100000469/penyebabpencemaran-udara?page $=$ all.

LIPI, Civitas. "No Title.” Last modified 2015. lipi.go.id.

Mamahit, Ferry Yefta. "Apa Hubungan Porong Dengan Yerusalem? : Menggagas Suatu Ekoteologi Kristen" (2007). http://repository.seabs.ac.id/handle/123456789/144.

Novalina, Martina. "Spiritualitas Orang Kristen Dalam Menghadirkan Kerajaan Allah Di Tengah Tantangan Radikalisme.” Jurnal Teologi Kontekstual Indonesia 1, no. 1 (June 29, 2020): 26.

https://journal.sttsimpson.ac.id/index.php/JTKI/article/view/293. 
Putri, Agustin Soewitomo. "Tips Dan Trik Pemilihan Dan Penyusunan Literatur Review." In Strategi Menulis Jurnal Untuk Ilmu Teologi, 49-50. Golden Gate Publishing, 2020.

Rendtorff, Rolf. "'Where Were You When I Laid the Foundation of the Earth?: Creation and Salvation History." In Bunga Rampai Teologi Perjanjian Lama, 25. 7th ed. Jakarta: BPK Gunung Mulia, 2015.

Sipahutar, Roy Charly. "Kajian Ekoteologis Tentang Konsep Tanah Dalam Perjanjian Lama Dan Implikasinya Bagi Pemeliharaan Tanah." BIA': Jurnal Teologi dan Pendidikan Kristen Kontekstual 2, No. 2 (2019).

Tanbunan, Gideon Imanto. Shalom: Paradigma Holistis Dalam Perjanjian Lama Dalam MIsi Holistis. Jakarta dan Bandung: Institute for Community and Development Studies, 2003.

VOA Indonesia. "BNPB: Banjir Bandang Sentani Akibat Ulah Manusia Yang Merusak Alam." VOA Indonesia. Last modified 2019. Accessed December 21, 2020. https://www.voaindonesia.com/a/bnpb-banjir-bandang-sentani-akibat-ulahmanusia-yang-merusak-alam/4836093.html.

Waltke, Bruce K.; Yu, Charles. An Old Testament Theology. Grand Rapids: Zondervan, 2007.

Westermann, Claus. “Creation.” In Bunga Rampai Teologi Perjanjian Lama, 20-21. 7th ed. Jakarta: BPK Gunung Mulia, 2015.

Wilkinson, Loren. "Kegundahan Hati Nurani Umat Manusia: Menemukan Kembali Ciptaan Di Dalam Gerakan 'Lingkungan' Dalam Allah Dan Kebudayaan.” In Kumpulan Esai Untuk Memperingati Ulang Tahun Carl F. H. Henry Ke-80, edited by John D. Carson, D. A. \& Woodbridge. Surabaya, 2011.

"Kebakaran Hutan Dan Lahan Kian Meluas Dan Kabut Asap Semakin Parah, BNPB Kewalahan Padamkan Api." BBC News Indonesia. Last modified 2019. https://www.bbc.com/indonesia/indonesia-49708970. 